\title{
Panorama of Onion Production in Tillabéri, A Region of the Far West of Niger
}

\author{
Maman Moustapha Rabiou \\ Idrissa Moussa \\ Tchicama Mella M. \\ Hassimi Sadou
}

Département de Chimie, Faculté des Sciences et Techniques, Université Abdou Moumouni, Niamey, Niger

Doi: 10.19044/esj.2018.v14n15p175 URL:http://dx.doi.org/10.19044/esj.2018.v14n15p175

\begin{abstract}
The objective of this study was to evaluate onion production systems in four municipalities along the Niger River. A cross-sectional survey was carried out among seventy-five onion producers distributed over ten perimeters. The results obtained reveal that onion is mainly grown by women (95\%). $70 \%$ of the farmers own the farmed land, $20 \%$ rent and $10 \%$ borrow. The cultivation takes place between September and March. The cultivated varieties are 'Galmi violet' and 'Gothèye white', Onions are essentially transformed into Gabou, a traditional condiment. The areas exploited are generally less than half a hectare. Irrigation relies mainly on the gravity system. NPK fertilizer and urea in combination with manure are the most commonly used. For phytosanitary treatments, producers use pesticides and/or natural products based on aqueous extract. At harvest time, the price per 100 $\mathrm{kg}$ bag varies from 8000 to 15000 FCFA (12 to $23 €$ ) and from 40000 to 50 000 FCFA (61 to $76 €$ ) after four months of storage. The average production cost per hectare is 1208564 FCFA (1844 €) and that of the net margins 551 857 FCFA $(840 €)$. There is a low correlation between strong investments and net margins. The major constraints faced by producers are the high cost of agricultural inputs, the rapid drying up of water points, limited access to credit, the straying of animals, the collapse of prices during the harvest period and the difficulties of farming storage and conservation.
\end{abstract}

Keywords: Onion, Cultivation, Gabou condiment, constraint, Niger

\section{Introduction}

Onion (Allium cepa L.), is a species of the family of Alliaceae (formerly Liliaceae s.l.), originating from Asia. It is a herbaceous plant of 
temperate climate, perennial by its unique bulb (Renaud, 2003). It is a vegetable used for its nutritional and therapeutic properties (Roldan et al., 2009). In the world, onions are one of the most widely grown vegetables (Sutevee et al., 2006). In Niger, the main vegetable is onion with 18,889 hectares or $41.21 \%$ of the total area planted with vegetables (MDA, 2011). Onion is produced for local consumption and for export. In Niger, It is grown mainly in the dry season under irrigation. Despite its traditional production, onion has emerged as one of the main export crops for two decades (MDA, 2009 Niger is the second largest onion producer in West Africa (Boukary et al., 2012) but the largest exporter (Eplucher oignon, 2010). Indeed, more than $95 \%$ of the national production is exported. Annual national production is estimated at nearly 561,000 tons (Boukary et al., 2012). The sector represents an economic activity of great importance, it generates nearly 47 billion FCFA (72 $000000 €$ ) of benefits to the agricultural economy (Boukary et al., 2012). Onions are produced nationwide but in varying proportions (PRODEX, 2009). The region of Tillabéry, located in the extreme west of Niger, is the third onion producing region in the country in 2013. Its annual production is estimated at about 37,160 tons (MDA, 2013). It is a region where the majority of onions is transformed into Gabou condiment. Our goal ultimate goal is to promote this traditional product and to achieve this, we first need to appreciate the whole value chain of onion production since its availability is a major factor in the production of Gabou. During this study, we surveyed onion growers to better understand the problems of the sector in the region. We evaluated the onion production system of five large municipalities in the region that make a significant contribution to regional production.

\section{Methodology}

Seventy-five (75) onion producers spread over ten (10) collective and individual irrigated farms were surveyed. On average, seven (7) producers were surveyed per collective area. The choice of onion producers and areas was random. The survey was conducted from September 2015 to April 2016 in the following localities: Saguia, Nordiré, Yoreizé-Koira, Tallé, GarbeyKouro, Kobe, Saya, Gothèye, Sakoira and Gougo-kore. These localities are distributed in five municipalities: Niamey 5, Namaro, Gothèye, Sakoira and Ayerou (figure.1). The types of data collected concern: the socio-economic profile of the producers, the cultural practices, the profitability of onion production and the difficulties encountered.

To analyze the profitability of the production, a sample of seven (7) producers spread over two municipalities were followed from the beginning until the end of the production. During the follow-up, all the expenses, i.e. those related to the production and marketing, as well as the numbers of bags of $100 \mathrm{~kg}$ of onion obtained at harvest were noted. This allowed us to 
determine: the total charges per unit area, the gross product (BP) per unit area and the net margin $(\mathrm{MN})$ through the formulas below:

$\mathrm{PB}=$ total production $*$ sales price and $\mathrm{MN}=$ gross product - total expenses. Calculated PB does not take into account the volume of selfconsumed and donated production.

Statistical analyzes: The data collected were analyzed. For qualitative data, a content analysis has been performed. For quantitative data, descriptive analyzes and financial profitability analyzes were performed. These analyzes were performed with the Minitab 16 software.

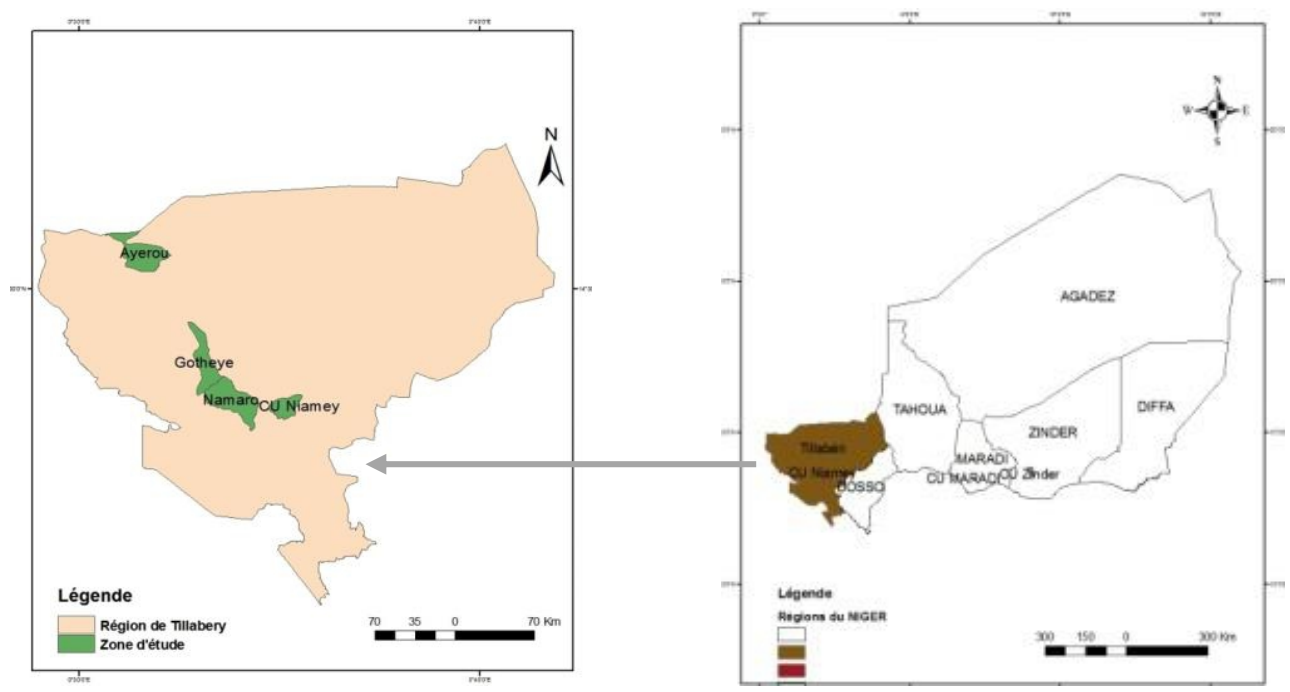

Figure 1: map of the study area

\section{Results and discussions}

\section{Socio-economic profile of producers}

\section{Age, sex and marital status}

The age of the producers varies between 15 and 60 years with an average of 40 years. About $95 \%$ of producers are women. In fact, men prefer jobs elsewhere, which they believe much more profitable than market gardening. Moreover, staying without going into exodus for work is perceived as a weakness in these villages. In addition, women easily receive more financial support than men. This is amply illustrated on internet areas madeup by financial backers. Indeed, the distribution of plots on these sites is largely in favor of women. However, the individual area of onion cultivation by women is generally smaller than that of men. More than $95 \%$ of producers are married. 


\section{The number of years of the trade practice}

Most of onion producers have an experience varying from 1 to 20 years and begin this activity at an early age for the benefit of their parents.

\section{School level}

$80 \%$ of producers surveyed did not attend school. The remaining $20 \%$ have been educated but only at primary school level. This low level is very often negatively influences the acquisition and use of good quality agricultural inputs. It also limits access to research results. This could influence the training of the producers on the techniques of production and conservation of the onion, thus reducing the profitability of this activity.

\section{Training on production technique}

Almost all of the producers surveyed attended at least one training session on the technical route of onion production. However, these courses are short-term. In general, producers mainly learned how to grow onions from their parents. The know-how is passed on from mother to children. Continuous information from producers could improve the profitability of onion production. To better improve the profitability of onion production, the training of producers on the production technique should be done on a regular basis with the participation of all the producers, not only of their representatives. But, it must be also accompanied by training on modern methods of marketing, a much neglected aspect.

\section{Workforce}

The production of good quality onions and the obtaining of an optimum yield require from the producers sustained and permanent efforts. Indeed, onion culture has a relatively long developmental life cycle (120 to 140 days) which requires, from transplanting to harvesting, intensive care, daily phytosanitary controls and a constant succession of delicate cultural operations (Issa et al., 2007). According to the results of the survey, the number of people associated with onion cultivation in the plots varies from 1 to 15 . The survey also revealed that the labor force is essentially family-based. In fact, over $88 \%$ of producers use their family members. Only about $12 \%$ of producers work with hired labor.

\section{Cultural practices of producers}

\section{Areas, land tenure and yields}

At the level of the study area, onion cultivation here is mainly done along the Niger River and its tributaries, on clay loam and sandy soils. Indeed, onion can be grown on different types of soils (Smith et al., 2011). However, it prefers soils of pH 6.0 to 6.8 (Katherine, 2006), light and fertile (Renaud, 2003), shallow, well-drained, with good exchange capacity, due to its poorly 
developed root system (Thorup-Kristensen, 2006). According to D'Alessandro and Soumah (2008), in West Africa, the areas planted are between 0.3 and 1.5 ha and most of these producers are smallholders. The area planted by producers in the Tillabéri region is still smaller, ranging from 0.03 to 0.5 ha. The development of an irrigation network can help increase the area of production. This could boost production, thus making it possible to move from a small scale of production, intended essentially for self-consumption and small business, to a large scale of production. Regarding land tenure, the development of land by the owner (direct mode) is mostly practiced. It represents $70 \%$ followed by sharecropping (20\%) which consists of renting the land. Payments are usually made in kind with a fraction of the harvest or cash. Finally, the loan represents $10 \%$, it is the free exploitation of land by non-owner. This mode is to be encouraged because it allows poor people to market gardening but also it maintain and restore soil fertility by burying organic or chemical fertilizers. For yield, it varies from one producer to another. In the Tillabéri region, the average yield is estimated at $32.69 \mathrm{t} / \mathrm{ha}$ for the 2012-2013 crop year (MDA, 2013). This yield is higher than the average world yield estimated at $17 \mathrm{t} / \mathrm{ha}$ (FAO, 1999). But it is below the highest average yields, which are between 41 t/ha and 62 t/ha in Korea, Japan, Europe and the United States. The best producers obtain harvests that exceed $100 \mathrm{t} /$ ha (D'Alessandro and Soumah, 2008). Improved technical production methods achieve promotes the good yields.

\section{Cultural calendar}

As shown in Table 1, only one onion season is recorded per year. It is mainly in the cold dry season. This observation is similar to that of D'Alessandro and Soumah, 2008. According to these authors, onion production in West Africa is largely in the dry and cold months. In general, in the study area, the campaign starts in late September and ends in early April. This is a period of 6 months of relatively favorable activities for onion production. In fact, onion is a cool season crop that prefers temperatures between $13^{\circ} \mathrm{C}$ and $24^{\circ} \mathrm{C}$. Its growth is slowed down when temperatures reach $30^{\circ} \mathrm{C}$ or more. (Rubatzky and Yamaguchi, 1997). However, some growers experiment with growing in the hot dry season. They start transplanting in mid-February and harvest at the end of June. The goal is to avoid concomitant harvesting but also to reduce storage time. Thus these producers reach, with a short storage period, the period of scarcity of the onion on the market. The loss due to the long storage period is thus avoided but also higher prices are obtained. Ignorance of the cultivation methods, the lack of adapted cultivars and the distance from the water points during the hot dry season severely limit the cultivation of the onion during this period. According 
to these producers, the 'Galmi violet' adapts better than the 'Gothèye white' to the hot dry season. The latter is grown almost exclusively in the cold season.

Table I: Onion production schedule at the study area

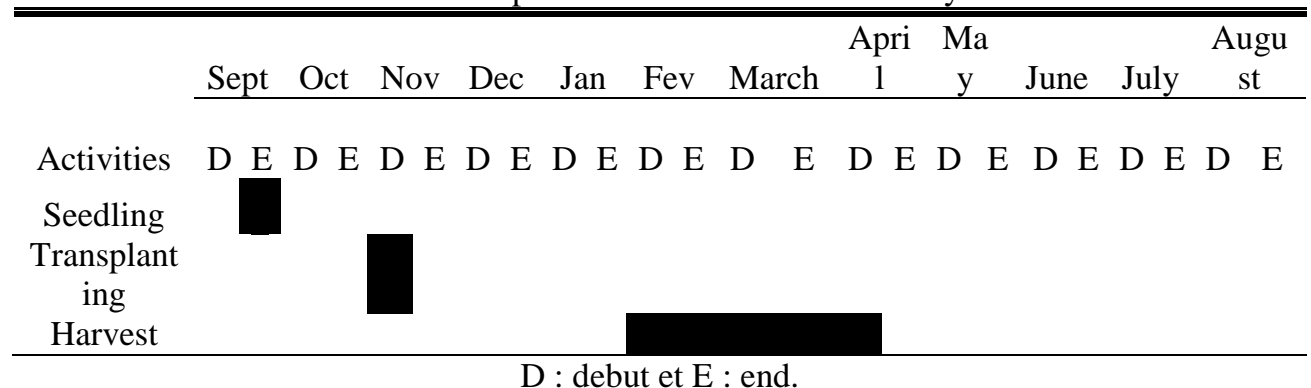

\section{Production systems}

Water sources, irrigation and catchment system

The most popular source of water for producers to irrigate plants is the Niger River. Thus, $80 \%$ of the producers use this water, $15 \%$ water from River Niger tributaries such as Dargol and the remaining farmers use water from wells. The withdrawal of water, following by low water level and high evaporation during the hot season but also to silting, leads to the remoteness of water sources. This causes, the early harvesting of the onion by some producers, especially by those who use manual watering devices. This is not without consequences on the quality of the harvested product. And for those who use motor pumps as a watering means, the induced loads increase. The construction of storage basins and redistribution, under the effect of pressure, water lifted by motor pumps could minimize the induced loads.

Regarding irrigation, poor management such as excessive water intake can cause bulb rot, the development of certain diseases such as Botrytis (Collin et al., 2004) and flowering in the first year of cultivation (Sanon et al., 2001). This latter situation has been observed on certain plots at the level of the study area. It has been reported that such a situation leads to the production of bulbs of poor quality thus causing damage to the commercial yield (Sanon et al., 2001). Under irrigated farm conditions in Niger, the total water requirement is $730 \mathrm{~mm}$ in 24 weeks. This need is distributed as follows: $50 \mathrm{~mm}$ pre-irrigation before transplantation; $32 \mathrm{~mm} /$ week ( $4.5 \mathrm{~m} /$ day) for 10 weeks; $60 \mathrm{~mm} /$ week ( $9 \mathrm{~mm} /$ day) for 3.5 weeks and finally $50 \mathrm{~mm} /$ week ( $7 \mathrm{~mm} /$ day) for 3 weeks. Irrigation frequencies vary from one area to another (Assoumane \& Hilali, 1994).

The mastery of irrigation techniques is therefore necessary to obtain optimal performance but also to effectively dampen production costs. The furrow irrigation system and the California irrigation system are the two main irrigation systems used in the study area. According to the results of the survey, the furrow irrigation system is largely dominant with nearly $90 \%$ 
irrigated area, followed by the Californian irrigation system which accounts for about $10 \%$ (Figure 6). The first system is a non-water saving technique. Indeed, the irrigation system to the line causes very significant water losses due to evaporation and infiltration during transport. These increase the costs of production due to the large purchase of fuel and the maintenance of motor pumps as the water is sent by the latter. It also promotes the development of weeds that can compete with the onion thus preventing its development. Despite the benefits it offers such as water savings, the use of the California system is low because of its high installation cost relative to producer revenues. In general, it is financed and installed by NGOs and projects.

Regarding the watering means, $90 \%$ of producers use motor pumps against $10 \%$ using the watering can. However, when onion is in the nursery, it is the watering can which is most often used for water supply. In general, the motor pump belongs to a group of producers, which sometimes makes it difficult to manage. The motor pump is an excellent watering means (optimal efficiency) but it generates costs due to fuels, maintenance and depreciation.

\section{Culture systems}

At the level of the study area, the onion plot is subdivided into beds of rectangular or square shape of variable size, ranging from $5 \mathrm{~m}^{2}$ to $12 \mathrm{~m}^{2}$. On the edges of boards, growers sometimes grow sweet potato or Moringa oleifera or corn/maize. The latter protects onion culture against violent winds and bio-aggressors. On the boards, onion is grown as pure crop. However, alongside the planks of onions can coexist other off-season crops, but the cultivation of onion occupies most of the planted areas. Pure onion cultivation is explained by the fact that onion does not tolerate competition with other crops as demanding as it is in terms of nutrient and water absorption, space and photoperiodism (Dunan et al., 1996; Kizilkaya et al., 2001; Ghosheh, 2004; Qasem, 2006 and Smith et al, 2008). Because of its slow growth, its roots are shallow and lack adequate foliage (Wicks et al., 1973). Onion production from transplants is the most widely practiced method by growers in our study area. However at the time of transplanting, the respect of the spacing between the plants is not taken into account by the producers. Optimal inter- and intra-rank spacings between plants for best performance depend on agro-climatic conditions. Geremew et al. (2010) recommended intra-row spacing of $4 \mathrm{~cm}$ and $6 \mathrm{~cm}$ depending on the cultivars in the central areas of the Rift Valley in Ethiopia. For the same cultivars, Kahsay et al. (2014) recommended intra-row spacing of $5 \mathrm{~cm}$ in Aksum northern Ethiopia (Kahsay et al., 2014). At Dargai, Malakand agency, inter and intra-row spacings of $22 \times 9.5 \mathrm{~cm}$ are considered the best for growing onions (Jan et al., 2003). Kishor et al. (2017) reported, meanwhile, spacings of $10 \times 10 \mathrm{~cm}$. In Niger, $15 \times 15$ $\mathrm{cm}$ spacings yielded a yield of up to $61.9 \mathrm{t} /$ ha with 'Galmi violet' (Assoumane 
\& Hilali, 1994). Several authors reported that the higher the density of plants the higher the yield of the resulting bulb is better (Jan et al., 2003; Kantona et al., 2003; Russo, 2008 and Kahsay et al., 2014). In addition, it has been reported that high densities also yield bulbs with better shelf-life and a more reliable start percentage of rot (Assoumane \& Hilali, 1994). Non-compliance with spacing leads to bulb production of heterogeneous sizes. In fact, the larger the difference between two plants, the larger the resulting bulbs (Kahsay et al., 2014). This is not without impact on shelf life since large bulbs are have shorter shelf life than medium sized bulbs (PRODEX 2012).

\section{Cultivated varieties}

Cultivated varieties are 'Gothèye white' and 'Galmi violet'. However, the production of these two cultivars varies from place to place in the study area. Thus, in the municipalities of Gothèye and Sakoira, it is the production of 'Gothèye white' which predominates while in the communes of Ayerou and Namaro it is 'Galmi violet' which is the most produced. 'Gothèye white' is exclusively produced to be processed into Gabou, a local condiment, because of its high dry matter content and the desired organoleptic quality of its Gabou. 'Galmi violet', on the other hand, is directly marketed because of its good appearance. However, small bulbs and those in early decomposition are used in the production of Gabou. Some producers produce both types of cultivars. However, in the case of non-compliance with isolation, the production of several varieties at the same zone level often leads to problems of exchange of pollen between different varieties (Agro-Bio, 2011).

\section{Diseases and pests}

The main onion pests in the study area are Thrips and grasshoppers. Thrips is a very small (about $2 \mathrm{~mm}$ ) sap-sucking insect found on the inside of the base of new leaves (Armeflhor, 2007). Poor management of thrips infestations results in a significant reduction in yield (Lewis, 1997). The main mode of control of this pest is the use of insecticides (Morse and Hoddle, 2006 and Nault and Shelton, 2010). However, over-reliance on insecticides may result in resistance development in onion thrips populations as previously reported (Shelton et al., 2003, 2006; MacIntyre-Allen et al., 2005a; Martin et al., 2003 and Herron et al., 2008). Phytosanitary monitoring and the use of resistant cultivars are the keys to minimizing the losses caused by onion thrips (Gillet et al., 2015). In addition to thrips and grasshoppers, at the conservation stage black rot is caused by Aspergillus niger.

\section{Harvest}

Onion harvest in the study area, is done manually. It takes place between early February and late March in early sown parcels that is in late 
September. While in late sown plots, harvest begins in late March and ends in late April. These harvest periods are essentially the same as those of the other regions of Niger, Benin and Burkina Faso (PRODEX, 2012; Tarchiani et al., 2013 and D'Alessandro and Soumah 2008). For these countries, the periods of full production are between March and April. A good harvest respects a certain number of principles (PRODEX, 2012):

$\checkmark \quad$ Harvest when $2 / 3$ of the leaves are lying down but are still green;

$\checkmark \quad$ Onions harvest during the cooler periods of the day (early morning and / or late evening);

$\checkmark \quad$ Onions harvest with leaves (at least $15 \mathrm{~cm}$ above the collar);

$\checkmark \quad$ Collars should be cut if necessary, about 4 to $5 \mathrm{~cm}$ above the bulb to avoid damaging the fleshy tissue of the bulb.

However the survey revealed that the majority of producers neglect some of these fundamental principles for a long-chain marketing product such as onion. Indeed, some growers practice first the effanage before detaching the bulbs, a practice considered unfavorable for a good conservation of onion (Eplucher oignon, 2010). In addition to this, during digging, there are injuries to some bulbs.

\section{Storage and conservation}

After harvest, the bulbs intended for marketing are dried for a few days (for at least 48 hours) in the sun and then sorted (by eliminating abnormal, flowering, injured, rotten, bifid, sick bulbs), sized, packed and preserved under the shade of trees, sheds or warehouses. However, there is a scarcity of improved onion storage stores in the study area. A good storage store increases the shelf life but also the market value of onion. In Niger, the stores known as Réséda and Rudu are the types of modern stores encountered with respectively a storage capacity of 20 tons for a period of six months and 6 tons for a period of five months. The loss rate of these stores is about 15\% (PRODEX, 2012). The onion's shelf life depends on a number of factors such as variety type, moisture content, bulb size, maturity at harvest and the weather conditions in which onion is stored (D'Alessandro and Soumah, 2008). Among climatic conditions, temperature and relative humidity are two important factors to control in order to store bulbs for a long time. Thus they can be stored at a low temperature which must not be lower than $2^{\circ} \mathrm{C}$ because of the risk of frostbite or at an elevated temperature above $28^{\circ} \mathrm{C}$. Due to the high cost of electricity, it is not often recommended to keep the bulbs cold (Ansari, 2007). The circulation of air in the storage room is extremely important to prevent the accumulation of condensation on the bulbs. Humidity ranging from 60 to $75 \%$ is ideal (Agblor and Waterer, 2001). Galmi violet disposed on storage racks can be stored for five months at room temperature (Boukary et al., 2012). 


\section{Agricultural inputs \\ Seed production}

Seed production plays a key role in onion cultivation and is a highly specialized activity requiring special knowledge (Khokhar, 2014). According to the results of our surveys, only a few producers specialized in the production of onion seeds. However, the local production of seeds in quantity and quality could allow producers avoid the purchase of imported seeds which are most often expensive and of undesirable quality. The main constraint of the production of seeds of onion, in many tropical countries, is the lack of cool weather to induce flowering (Peters, 1990). Indeed, optimum flowering temperatures are between $5^{\circ} \mathrm{C}$ and $13^{\circ} \mathrm{C}$ for 90 to 120 days (Currah and Proctor, 1990 and Khokhar, 2009). Flowering is greatly reduced or suppressed at temperatures between $15.5^{\circ} \mathrm{C}$ and $30^{\circ} \mathrm{C}$ and at low temperatures between $3^{\circ} \mathrm{C}$ and $0^{\circ} \mathrm{C}$. In addition, the temperature at which onion bulbs are stored influences the time required for flowering plants. Thus, it has been shown that storage temperatures ranging from $7^{\circ} \mathrm{C}$ to $12^{\circ} \mathrm{C}$ induce flowering earlier than the lowest or highest temperatures (Jones and Emsweller, 1939 and Jones, 1927). In a literature review, it was concluded that onion cultivars appear to differ somewhat in their optimal temperature requirements depending on the locality to which they are adapted (Khokhar, 2014). The best yield of onion seeds is obtained with large bulbs (Morozowska and Holubowicz, 2009; Aminpour and Mortazavibak, 2004).

\section{Use of chemical and organic fertilizers}

The general objective of fertilization is to provide the plant with nutrients in quantity and quality when it is needed. However, its poor application contributes to soil degradation and a decline in yield.

Despite the high cost of chemical fertilizer and its scarcity in markets and agricultural input shops, almost all producers in the study area use it on their plots. The most used types of chemical fertilizers are NPK and urea. However, the producers most often do not respect the recommendations of fertilizer doses to be applied. Manure is also used by almost all producers. It has been reported that in Niger and Burkina Faso organic fertilizers are widely appreciated by producers. However, these fertilizers are available in small quantities and are mostly unavailable at planting time (D'Alessandro and Soumah, 2008).

It is important to control fertilization well. In fact an excessive intake of nitrogen at the beginning and at the end of the cycle causes the weakening of the plants by making them more susceptible to diseases, delaying their maturity and accentuating the problems of bursting of the double hearts. The last nitrogen supply must therefore be carried out at most one month before the harvest (Armeflhor, 2007). It has been reported that the use of nitrogen at 
a level of $150 \mathrm{~kg} / \mathrm{ha}$ produces more bulbs and gives a high dry matter yield (Fatideh and Asil, 2012). Phosphorus plays a key role in rooting. This element, which is not very mobile in the soil, must be brought before the return of plowing for traditional fertilization. To promote a better conservation of the bulbs, the potash must be brought during the bulbaison. A contribution of trace elements at the 5-6 leaf stage makes it possible to limit the risk of deficiencies (Armeflhor, 2007). Onion is rich in sulfur compounds. It is therefore important to favor fertilizers containing sulfur (sulphate). This element increases the yield but also improves the quality of the bulb, in particular the spiciness and the aromas (Jaggi and Dixit, 1999). In addition, to guide fertilizer applications, soil analyzes must be performed (Katherine, 2006).

The use of manure by growers should be encouraged as it improves soil structure, which can promote root development and thus good plant growth (Singer et al., 1998). Its use also reduces environmental pollution and production costs. In addition, it is recommended to keep onions for a long time a contribution of 10 to $20 \mathrm{t} /$ ha of organic manure based on goat droppings, cow dung and poultry droppings with or without associated with 100 to 150 $\mathrm{kg}$ of NPKSB compound fertilizer and 50 to $100 \mathrm{~kg}$ urea per hectare in Niger (Bello et al., 2001; Bello et al., 2002).

On a flat, well-drained sandy-loam soil rich in organic matter, the recommended amount of NPK and organic mineral fertilizer, from the beginning to the end of onion production in Niger, is distributed in the same way next (INRAN, 2011):

$\checkmark \quad 20 \mathrm{~g} / \mathrm{m}^{2}$ of NPK for the preparation of seedbed;

$\checkmark \quad$ In bottom manure, $2 \mathrm{~kg} / \mathrm{m}^{2}$ of decomposed organic matter and $10 \mathrm{~g} /$ $\mathrm{m}^{2}$ of NPK;

$\checkmark \quad$ In the manicure of maintenance, $10 \mathrm{~g} / \mathrm{m}^{2}$ of NPK in two contributions 40 days after transplanting and at the beginning bulb season is 75 to 80 days after transplanting.

\section{Use of pesticides}

The results of the survey indicate that almost all producers use pesticides. About 95\% of them use chemical pesticides (2-6 ET, capt 88EC, dimethanoate, cypercal) and 5\% use natural pesticides (ash, neem extract ...). However, most often, producers do not know which pesticide to apply in the face of a disease or pest. In addition, safe handling and pesticide application practices are not respected by producers. Which presents a danger for them but also for the environment (Nault et al., 2012, Jensen and Simko, 2001). The use of natural pesticides is to be encouraged since it is safe for the environment and human health. But also these natural pesticides are affordable where the materials are available locally. For these reasons, research of plants with effective insecticidal properties should be encouraged. Nicotiana glauca 
Grahama leaf extract has shown efficacy comparable to synthetic insecticides including dimethanoate 40\% EC and Lambda-cyhalothrin (Karate 5 EC) in the control of onion thrips (Fitiwy et al., 2015).

\section{Profitability of onion production Marketing}

To meet their needs, but also because of inadequate storage and conservation facilities, the majority of producers are forced to sell their onions at harvest. This does not allow them to enjoy the best prices since at this time the offer is very important. The bulk of the sale is in local markets and around the fields. Only a few producers manage to bring their onions to the markets of the capital (Niamey). The selling price of the $100 \mathrm{~kg}$ bag varies between 8,000 to 15,000 FCFA (12 to $23 €$ ) during the harvest period. After 3 to 4 months of storage, the same bag costs between 40,000 to 50,000 FCFA (61 to $76 €)$. Producers deplore the lack of wholesalers in their production area.

\section{Profitability and sources of onion production financing}

According to the majority of producers surveyed, onion production is profitable. In order to evaluate this profitability and identify the factors that influence it, a sample of seven producers distributed in two localities were followed. During the evaluation, all the charges, ie those related to production and marketing, were mentioned and the number of bags of $100 \mathrm{~kg}$ of onion harvested was counted. This allowed us to estimate the gross margin of each producer (Table II) but also to establish a structuring of production costs (Figure 2).

Table II: Charges, products and net margins in Fcfa per hectare of producers

\begin{tabular}{llllllll}
\hline Designations & Pro. A & Pro. B & Pro. C & Pro. D & Pro. E & Pro. F & Pro. G \\
\hline \hline Seed & 150000 & 156250 & 156250 & 187500 & 41625 & 62500 & 30000 \\
Phyto. products & 15000 & 87500 & 62500 & 62500 & 4995 & 15000 & - \\
Org. manure & 25000 & 25000 & 9375 & - & 16650 & - & - \\
Chim. Fertilizer & 450000 & 562500 & 562500 & 562500 & 15984 & 27500 & 21375 \\
Workforce & 660000 & 356250 & 318750 & 443750 & 256410 & 315000 & 177500 \\
F.E.O & 450000 & 312500 & 312500 & 375000 & 146121 & 169000 & 114500 \\
R.P.D.M & 105000 & 87500 & 125000 & 225000 & 89910 & 56500 & 53750 \\
Prod. costs & $\mathbf{1 8 5 5 0 0 0}$ & $\mathbf{1 5 8 7 5 0 0}$ & $\mathbf{1 5 4 6 8 7 5}$ & $\mathbf{1 ~ 8 5 6 2 5 0}$ & $\mathbf{5 7 1 ~ 6 9 5}$ & $\mathbf{6 4 5 5 0 0}$ & $\mathbf{3 9 7} \mathbf{1 2 5}$ \\
Sale charges & 285000 & 118750 & 190000 & 125000 & 79254 & 75000 & 142500 \\
Total charge & $\mathbf{2 1 4 0 0 0 0}$ & $\mathbf{1 7 0 6 2 5 0}$ & $\mathbf{1 7 3 6 8 7 5}$ & $\mathbf{1 9 8 1 2 5 0}$ & $\mathbf{6 5 0 9 4 9}$ & $\mathbf{7 2 0 5 0 0}$ & $\mathbf{5 3 9 6 2 5}$ \\
Raw products & $\mathbf{3 0 0 0 ~ 0 0 0}$ & $\mathbf{1 2 5 0 0 0 0}$ & $\mathbf{2 0 0 0 0 0 0}$ & $\mathbf{2 5 0 0 ~ 0 0 0}$ & $\mathbf{1 1 3 2 ~ 2 0 0}$ & $\mathbf{1 5 0 0 ~ 0 0 0}$ & $\mathbf{1 5 0 0 ~ 0 0 0}$ \\
Net margins & $\mathbf{0 0 0}$ & 456250 & $\mathbf{2 6 3 1 2 5}$ & $\mathbf{5 1 8 7 5 0}$ & $\mathbf{4 8 1 2 5 1}$ & $\mathbf{7 7 9 5 0 0}$ & $\mathbf{9 6 0 3 7 5}$ \\
\hline
\end{tabular}

- : Not used; Pro. : Producer; Phyto.: Phytosanitary; Org.: organic; Chem.: chemical;

R.P.D.M: Rental, Purchase and Depreciation of Materials; F.E.O: Fuel \& Engine Oil; prod:

production. 
Producers A, B, C and D are from Gothèye municipality and producers E, $\mathrm{F}$ and $\mathrm{G}$ are from Ayerou municipality. Margins have been calculated on a provisional basis. A selling price of 10,000 Fcfa (15.25€) per $100 \mathrm{~kg}$ bag (price at the end of the harvest in April) was retained for all producers. The analysis in Table II shows that production costs per hectare vary from 397,125 to $1,856,250 \mathrm{Fcfa}$ (605.61 to $2830.78 €$ ). The average production cost is $1,208,564$ F CFA $(1,844 €)$. Production costs are about four times higher in Gothèye than in Ayerou. The average cost of production reported during this study is slightly less than 1,262,691 and 1,520,000 FCFA reported respectively to the province of Yatenga in Burkina Faso for the 2012-2013 campaign (Inessa, 2013) and Senegal (CGERV, 2015). While it is about twice as high as 743,000 Fcfa reported from Malanville in Benin (Tarchiani et al., 2013). Concerning the raw products of these producers at harvest, they vary from $1,132,200$ to $3,000,000 \mathrm{~F} \mathrm{CFA}(1,726.60$ to $4,575 €)$. The average of these raw products is $1,730,367$ F CFA $(2,638.81 €)$. In general, the highest raw products were obtained by producers in Gothèye. For profit margins, all the producers monitored achieved positive net margins at the end of their campaign, except one which recorded a negative net margin of 456,250 F CFA ( $€$ 695.78). These net margins per hectare range from 263,125 to $960,375 \mathrm{~F}$ CFA (401.26 to $1,464.57 €$ ) with an average of 551,857 F CFA (840 €). The highest margin was obtained by the producer of Ayerou. For the 2015-2016 company, the average production costs, revenues and gross margins for producers in the Maradi region are respectively 695,139 F CFA $(1,060.08 €)$, 1,265,171 (1,929.38 €) F CFA and 570,032 F CFA (€ 869.29) (Guéro, 2016). According to these results, the production of onions requires more investment in Tillabéry than in Maradi. This could be due to the high cost of inputs in this area and / or the strong application of these. In fact, producers in the Maradi region are sourcing in neighboring Nigeria where agricultural inputs are relatively cheaper. The average gross product reported by this author is inferior to our results. Despite a retained sale price of 12,000 FCFA per bag of $100 \mathrm{~kg}$. Which means that the yield is higher in Tillabéri than in Maradi. Although it is the gross margin, it is roughly equal to the average net margins obtained during our study.

There is a weak correlation $\left(\mathrm{R}^{2}=0.23\right)$ between the level of investment and the realized margins. This could be due to non-mastery of the technical production route.

For a shelf life of 3 to 4 months, the margin will be multiplied by 4 . However, this margin will decrease when considering conservation costs and decay rates. The analysis in Figure 3 allowed us to explain this difference in production costs between producers. 


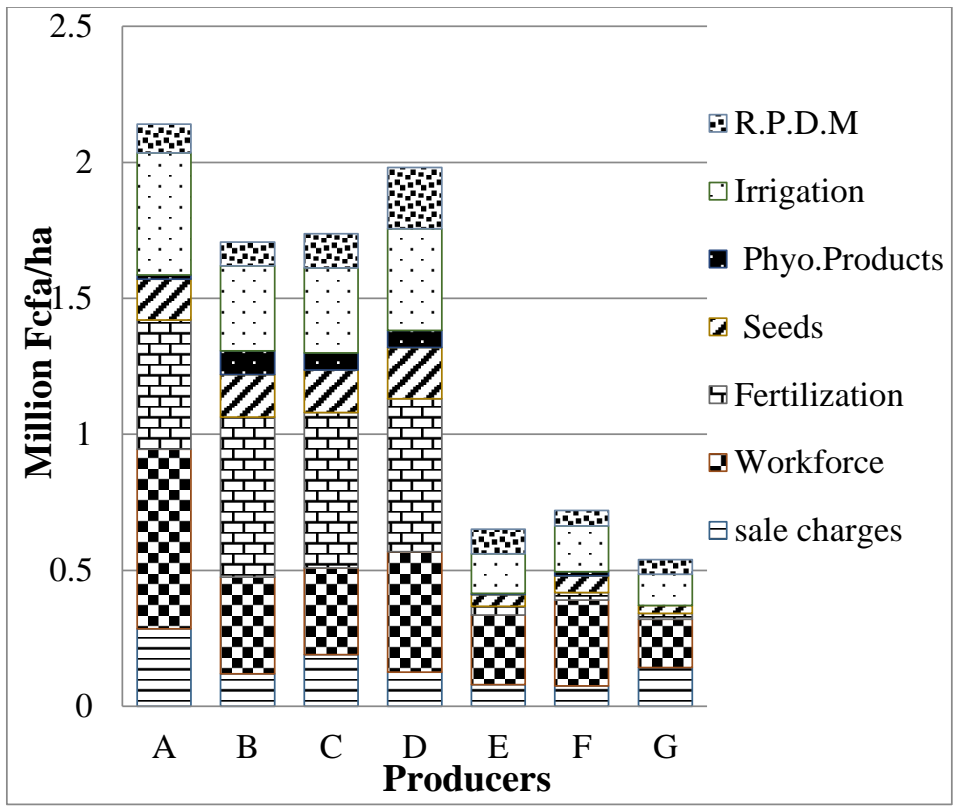

Figure 2: Structure of production costs

The producers of the municipality of Gothèye (A, B, C and D) apply large doses of fertilizers, seeds and phytosanitary products (except producer A, who has not done phytosanitary treatment at all). Irrigation is intensified and the workforce is strongly mobilized by these producers. This has resulted in high production costs. Nevertheless, the producers of the municipality of Ayerou (E, F and G) reduced at all levels the production costs, especially those of inputs. Indeed, these producers apply low doses of inputs but employ a large number of labor compared to other sources of expenditure. In fact, the average load of labor represents $38.67 \%$ of their production costs. In Niger, the cost of labor is almost half of the total costs of production (D'Alessandro and Soumah, 2008). Sales expenses consist of packaging, transport, packaging and tax. These charges are proportional to the amount of onions harvested by growers. Producers invest little in the acquisition of agricultural equipment. In fact, the purchase, rental and maintenance of small equipment accounts for $8.57 \%$ of their production costs. These materials are mostly traditional. It has been reported previously that in Niger, structural costs account for $10 \%$ of production costs. While they constitute 30 to $40 \%$ in Burkina Faso (D'Alessandro and Soumah, 2008). Overall, low investment capacity in agricultural mechanization has been reported in West Africa (Blein et al., 2008).

In general, producers finance production from family income. These are essentially obtained from the previous campaign, livestock and small business. Access to institutional credits is very limited. Because of this limited 
access and low income, producers rely on government donations, NGOs and projects that are mostly irregular, inadequate and late.

\section{Transformation}

The most popular onion processing in the study area is sun drying. Indeed, more than $80 \%$ of 'Gothèye white' onion production is destined for solar drying after crushing bulbs. The dried onion is intended for the manufacture of Gabou, a traditional condiment. Among the two cultivated varieties, 'Gothèye white' is most often intended for the manufacture of Gabou. The choice of this variety is motivated by the fact that it gives Gabou good organoleptic characters. Indeed, Gabou of this variety has a color, an aroma and a taste very appreciated by the consumers. In addition, for the same volume of fresh onion and in the same conditions of manufacture, 'Gothèye white' gives more Gabou than 'Galmi violet'.

\section{Encountered difficulties}

They are either related to production or marketing or both.

\section{Difficulties related to production}

The results of the survey revealed that agricultural inputs are relatively available in the area. But the majority of producers complain about the high cost of these inputs compared to their low self-financing capacity. For example, African producers pay between two and six times the average world price of fertilizer (Henao and Baanante, 2006). This high price makes it difficult to access these agricultural inputs. The lack of local seed production is one of the major problems for producers. This favors the purchase of cheap seeds. Indeed, it happens that the mentioned variety labelled is not the one mentioned on the box. It was reported that imported seeds cost between 40,000 and $60,000 \mathrm{FCFA} / \mathrm{kg}$ whereas those locally produced is about were reported as 20,000 FCFA/kg (D'Alessandro and Soumah, 2008). The majority of producers obtain seed from unauthorized traders. This favors the purchase of seeds of inferior quality. The supply of seed to traders can be explained by their availability and their affordable cost. Several authors have reported the difficulty of becoming pregnant in Africa and other African countries (Bewuketu et al., 2016 and D'Alessandro and Soumah 2008). It is important to point out the difficulty of finding quality seeds, coupled with their prohibitive cost often causes a delay in the start of activities. Also, producers encounter a phytosanitary problem. The persistence of this problem is due, most often, to the ignorance of the appropriate insecticides to be applied by the producers.

In addition, there is the problem of access to water at a certain time. Indeed, silting, strong evaporation and permanent flow of the river. In Niger, 
evaporation varies between $1,700 \mathrm{~mm}$ and $2,100 \mathrm{~mm}$ of water per year (FAO, 2016). These lead to the removal of water source plots the problem of irrigation. To solve this problem, the prospects offered by producers are diverse. For the majority, they need to get a grant or more, or through a credit. For others, it is necessary to install boreholes or dig wells or facilities. At the level of some irrigated perimeters, there are also difficulties in managing motor pumps.

In addition to the problems of inputs and irrigation, another major problem is the rambling of cattle and hippos. These animals are becoming devastate plots. If fence delimitation can limit the animal devastation, it is not effective against depredation by hippos. Many producers have abandoned the gardening market following the disappointment caused by them. To limit their damage, some producers spend the night on the plot. The producers want to be compensated by the state in case of damage caused by hippos.

\section{Difficulties related to marketing}

The main problem facing producers at the marketing level is the sale of their produce during the harvest period because of the supply that far exceeds the demand, resulting in a sudden price collapse. Indeed, onion market is an oligopsony, it is the buyers who set prices. This greatly reduces the profitability of onion production. Not only are prices low, but transport costs increase due to multiple round trips between home and weekly markets because of the slump. In addition, decay product losses increase primarily due to the lack of appropriate storage and conservation infrastructure. To remedy these problems, a market regulation strategy has been put in place by producers' supervisors. It consists of reducing the amount of onion placed on the market and setting a remunerative price. Unfortunately, despite the many sensitizations, producers can not adhere to this proposal because of poverty and lack or absence of appropriate storage and storage stores. Producers want it to have the arrival of economic operators who will buy their production in bulk.

For the sale of dried onion, the flow problem does not arise because the product is well preserved in this form. Which makes it possible to sell it little by little without any anxiety due to its decomposition.

\section{Conclusion}

At the end of this study on onion production, we told ourselves that:

- Onion production is a source of income and a significant source of income for many families. In general, this activity is performed by women. The area exploited by them is smaller than that of men. They do not go much to market gardening. A good part of the production of Gothèye white is transformed into Gabou. Producers have a low level of education. They are 
generally, small producers working on small areas generally less than half a hectare with most often traditional equipment.

- Production equipment is essential in low family income.

- Most of the onion sale is done in detail in local markets and around the fields. The price of onion on the markets varies according to the period. It is low during harvest period between February and April high 3 months after.

- The production costs borne by the producers in Gothèye are very high compared to their self-financing capacity. Those of Ayerou producers are average and reasonable. Onion production is a profitable activity. This profitability can be improved if some of the difficulties encountered by the productions are reduced.

\section{References:}

1. Agblor, S., \& Waterer, D. (2001). Peppers: post-harvest handling and storage: fact sheet. Canada I: Canada-Saskatchewan Irrigation Diversification Centre.

2. Agro-Bio. (2011). La production de semences d'alliacées. pp.4. Disponible sur:http://www.agrobioperigord.fr/upload/biodiv/fichealliacees.pdf. (Consulté le 09/06/17).

3. Aminpour, R., \& Mortazavibak, A. (2004). Mother Bulb Size and Planting Pattern Effects on Seed Quality and Quantity of Onion (Allium cepa L.) Cv. Texas Early Grano 502. Seed Plant. 20: 39-48.

4. Amoukou, A. (2006). Impacts des investissements dans la gestion des ressources naturelles sur les systèmes de production dans les régions de Maradi, Tahoua et Tillabéri, au Niger. pp. 31. http://www.hubrural.org/IMG/pdf/aspects_agronomie.pdf . (Consulté le 06/09/16).

5. Ansari, N. A. (2007). Onion Cultivation and Production in Iran. Middle Easter \& Russian J. Plant Sci. and Biotech. 1 (2): 26-38

6. Armeflhor. (2007). Production d'oignon à la Réunion-Guide pratique. 57

http://armeflhor.pagespersoorange.fr/publication/Production_oignon Reunion_Guide_pratique.pdf, (consulté le 19/11/14).

7. Assoumane, M., \& Hilali, A. (1994). L'AMELIORATION DE L'OIGNON (Allium cepa L.) AU NIGER. Bulletin de liaison $n^{\circ} 8 \mathrm{du}$ Réseau africain pour le développement de l'horticulture (RADHORT).

8. Bello, S., \& Afouda, O. Y. (2002). Rapport du voyage d'échanges d'expériences entre producteurs nigériens et béninois au Niger, INRAB-CRAN/PADSE, Bénin. 37 p.

9. Bello, S., Afouda O. Y., \& Assogba-Komlan, F. V. (2001). Le stockage et la conservation de l'oignon: Comment concilier les expériences des producteurs nigériens avec les réalités de ceux du 
Bénin? INRAB-CRAN/PADSE, Bénin.

10. Bewuketu, H., Tsegaye, B., \& Awalom H. (2016). Constraints in production of onion (Allium cepaL.) in Masha District, Southwest Ethiopia. Glob. J. Agric. Agric. Sci. 4(2) :314-321.

11. Blein, R., Soulé, B. G., Dupaigre, B. F., \& Vérima B. (2008). Les potentialités agricoles de l'Afrique de l'Ouest (CEDEAO), 116p.

12. Boukary H., Roumba A., Adam T., Barrage M., Saadou M. (2012). Interactions entre la variabilité des ecotypes de l'oignon (Allium cepa L.) et les facteurs agro-climatiques au Niger. Tropicultura 30(4): 209215.

13. CGER, (2015). Centre de Gestion et d'Économie Rurale de la Vallée. Analyse Économique sur la filière Oignon au Sénégal. RECA-Niger.

14. Collin, F., Brun, L., Jonis, M., Lelagadec, F., Lizot, J. F., Delmond, F., Broucqsault L. M., Serpeille, A., \& Laurent, E. (2004). Produire des semences d'oignon dans un itinéraire agrobiologique, fiche technique, TECHN'ITAB, $4 \mathrm{p}$.

15. Currah, L., \& Proctor, F. J., (1990). Onions in Tropical Regions. Natural Resources Institute Bulletin, 35.

16. D'Alessandro, S., \& Soumah A. (2008). Évaluation sous régionale de la chaîne de valeurs oignon/échalote en Afrique de l'Ouest. Bethesda, MD: projet ATP, Abt Associates Inc.

17. Dunan, C. M., Westra, P., Moore, F., \& Chapman, P. (1996). Modelling the effect of duration of Weed competition, Weed density and Weed competitiveness on seeded, irrigated onion. Weed Res 36: $259-269$.

18. Eplucher l'oignon. (2010). L'importance de l'oignon dans la vie socioéconomique du Niger: contexte et agendas d'action. 10pp.

19. FAO, (2013). Organisation des Nations Unies pour l'Alimentation et l'Agriculture. Rapport régional. AQUASTAT. Rome.

20. Fatideh, M. M., \& Asil, M. H. (2012). Onion yield, quality and storability as affected with different soil moisture and nitrogen regimes. South-west J Hortic Biol Environ. 3(2): 145-165.

21. Fitiwy, I., Gebretsadkan, A., \& Ayimut, K. M. (2015). Evaluation of botanicals for onion thrips, Thripstabaci Lindeman, (Thysanoptera: Thripidae) control at Gum Selassa, South Tigray, Ethiopia. MEJS. 7(1): 32-45.

22. Geremew, A., Teshome, A., Kasaye, T., \& Amenti, C. (2010). Effet of intra-row spacing on yield of three onion (Allium cepa $\mathrm{L}$.) varieties at Adami Tulu agricultural research center (mid rift valley of Ethiopia). J. Hortic. For. 2(1): 007-011

23. Ghoshel, H. Z. (2004). Single Herbicide Treatments for Control of Broadleaved Weeds in Onion (Allium cepa L.). Crop Prot. 23: 539-542 
24. Gill, H. K., Garg, H., Gill, A.K., Gillett-Kaufman, J. L., \& Nault, B. A., (2015). Onion Thrips (Thysanoptera: Thripidae) biology, ecology, and management in Onion Production Systems. Int. J. Pest Manag. 6(1): 6, DOI: 10.1093/jipm/pmv006.

25. Guéro, M. (2016). Résultats du conseil de gestion à l'exploitation agricole pour la culture de l'oignon / campagne 2015 - 2016. Pp 6. http://www.recaniger.org/IMG/pdf/CRA_Maradi_CGEF_Culture_oignon_2016.pdf. (Consulté le 06/09/16).

26. Habsatou, B., Roumba, A., Adam, T., Barrage, M., Saadou. (2012). Interactions entre la variabilité des écotypes de l'oignon (Allium cepa L.) et les facteurs agro-climatiques au Niger. Tropicultura. 30(4): 209215.

27. Henao, J., \& Baanante, C. (2006). Agricultural Production and Soil Nutrient Mining in Africa Implications for Resource Conservation and Policy Development: Summary An International Center for Soil Fertility and Agricultural Development; IFDC

28. Herron, G., James, T. M., Rophail, J., \& Mo, J. (2008). Australian population of onion thrips, Thripstabaci Lindeman (Thysanoptera: Thripidae), are resistant to some insecticides used for their control. Aust. J. Entomol. 47: 361-364.

29. Inessa, N. H. (2013). Etude diagnostique des techniques de production de l'oignon (Allium cepa L.) dans la province du Yatenga. Mémoire de Master. Université Polytechnique de Bobo-dioulasso (U.P.B), Institut du Developpement Rural (I.D.R). http://www.beep.ird.fr/collect/upb/index/assoc/IDR-2013-NAPETU/IDR-2013-NAP-ETU.pdf. (consulté le 16-02-2018)

30. INRAN, (2011). Fiche technique de production de bulbe d'oignon. 3pp. https://fr.scribd.com/document/283384973/3-Fiche-TechniqueINRAN-Production-Bulbe-Oignon-2011 (consulté le 28/09/2017).

31. Issa, M., Aboubacar, A. N., \& Idrissa, I. (2007). Evaluation des productions d'oignon et élaboration des stratégies de commercialisation Galmi. 16pp. https://www.doc-developpementdurable.org/file/Culture-plantes

alimentaires/FICHES_PLANTES/ailoignonechalotte/Evaluationdespr oductionsdoignonetelaborationdesstrategiesdecommercialisation_Nig er1679_.pdf (consulté le 22/09/2017).

32. Jaggi, R. C., \& Dixit, S. P. (1999). Onion (Allium cepa L.) responses to sulphur in representative vegetable growing soils of Kangra Valley of Himachal Pardesh. Indian J. Agric. Sci. 69: 289- 291.

33. Jan, N. E., Wazir, F. K., Ibrar, M., Mohammed, H., \& Ali, A. R. (2003) Effet of different inter and intra - row Spacing on the Groth and Yield 
of different cultivars of onion. Sarhad J. Agric. 19:4.

34. Jensen, L., \& Simko, B. (2001). Alternative Methods for Controlling Onion Thrips (Thripstabaci) in Spanish Onions. Malheur County Extension Service, Clint Shock and Lamont, Saunders, Malheur Experiment Station, Oregon State University, Ontario.

35. Jones, H. A. (1927). The Influence of Storage Temperature on Seed Production in the Ebenezer Onion. J. Am. Soc. Hortic. Sci. 24: 61-63.

36. Jones, H. A., \& Emsweller, S. L. (1939). Effect of Storage, Bulb Size, Spacing and Time of Planting on Production of Onion Seed. California Agricultural Experiment Station Bulletin.

37. Kahsay, Y., Belew, D., \& Abay, F. (2014). Effects of intra-row spacing on plant growth and yield of onion varieties. Afr. J. Agric. Res. 9(10): 931-940

38. Kantona, R. A. L., Abbeyb, L., Hillac, R.G., Tabil, MA., \& Jane, N. D., (2003). Density Affects Plant development and Yield of bulb onion (Allium cepa L.) in Northern Ghana. J. Veg. Crop Prod. 8:15-25.

39. Katherine, A. (2006). Organic Allium Production. National Sustainable Agriculture Information Service. www.attra.ncat.org/attra-pub/PDF/allium.pdf

40. Khokhar, K. M. (2009). Effect of Set-Size and Storage Temperature on the Incidence of Bolting, Bulbing, and Seed Yield in Two Onion Cultivars. Sci Hortic. 122: 187-194.

41. Khokhar, K. M. (2014). Flowering and Seed Development in OnionA Review. Open Access Library Journal, 1: e1049. http://dx.doi.org/10.4236/oalib.1101049

42. Kishor S., Ram, R. B., Meena, M. L., Kishor, S., Meena, D. C., \& Kumar, A. (2017). Influence of different spacing and cultivars on yield components and biochemical parameters of onion (Allium cepa L.). Biosci. Biotech. Res. Comm. 10(3): 415-418.

43. Kizilkaya, A., Onen, H., \& Ozer, Z. (2001). Researches on the effects of weed competition on onion yield. J. Turk. Weed Sci. 4(2): 58-65.

44. Lewis, T. (1997). Thrips as crop pests. CAB International, New York, NY.

45. MacIntyre-Allen, J. K., Scott-Dupree, C. D., Tolman J. H., \& Harris C. R., (2005a). Evaluation of sampling methodology for determining the population of onion thrips (Thysanoptera: Thripidae) in Ontario onion fields. J. Econ. Entomol. 98: 2272-2281.

46. Martin, N. A., Workman, P. J., \& Butler, R. C. (2003). Insecticide resistance in onion thrips (Thripstabaci) (Thysanoptera: Thripidae). N Z J. Crop Hortic. Sci. 31: 99-106.

47. MDA, (2011). Ministère du développement Agricole. Rapport final et résultats de l'enquête sur les productions horticoles 2010/2011. 
Directions des statistiques.

48. MDA, (2013). Ministère du développement Agricole. Résultats définitifs de l'enquête sur les productions horticoles 2012/2013. Directions des statistiques.

49. MDA, MRA. Ministère du Développement Agricole, Ministère des Ressources Animales. (2008). Recensement Général de l'Agriculture et du Cheptel (RAGC 2005-2007). Volume IX Résultats définitifs Horticulture. Projet FAO GCP/NER//EC.

50. MDA. Ministère du Développement Agricole. (2009). Plan d'actions opérationnel de la filière oignon du Niger. Projet de développement des exportations et des marchés agro-sylvo pastoraux (PRODEX), pp. $1-23$

51. MDA. Ministère du Développement Agricole. (2012). Guide de bonnes pratiques de production, stockage et conservation de l'oignon. Projet de développement des exportations et des marchés agro-sylvo pastoraux (PRODEX), pp. 1-10.

52. Morozowska, M., \& Holubowicz, R. (2009). Effect of Bulb Size on Selected Morphological Characteristics of Seed Stalks, Seed Yield and Quality of onion (Allium cepa L.) Seeds. Folia Hort. 21: 27-38.

53. Morse, J. G., \& Hoddle, M. S. (2006). Invasion biology of thrips. Ann. Rev. Entomol. 51: 67-89.

54. Nault, B. A., \& Shelton, A. M. (2010). Impact of insecticide efficacy on developing action thresholds for pest management: A case study of onion thrips (Thysanoptera: Thripidae) on onion. J. Econ. Entomol. 103: 1315-1326.

55. Nault, B. A., Hsu, C. L., \& Hoepting, C. A. (2012). Consequences of co-applying insecticides and fungicides for managing Thripstabaci (Thysanoptera: Thripidae) on onion. Pest Manag Sci, doi:10.1002/ps.3444.

56. Peters, R. (1990). Seed Production in Onions and Some Other Allium Species. In: Rabinowitch, H. D., \& Brewster, J. L., (Eds.), Onions and Allied Crops. Botany, Physiology and Genetics 1: 161-176. CRC Press, Boca Raton.

57. Qasem, J. R. (2006). Chemical Weed Control in Seedbed Sown Onion (Allium cepa L.). Crop Prot. 25: 618-622.

58. Renaud, V. (2003). Tous les légumes courants, rares ou méconnus, cultivables sous nos climats. Les éditions Eugen Ulmer. Paris. 224 p.

59. Roldan, E., Sanchez-Moreno, C., Lloria R., DE Ancos, B., \& Cano, M. P. (2009). Onion high-pressure processing: Flavonol content and antioxidant activity, LWT - Food Sci Technol. 42 (4): 835-841.

60. Rubatzky, V., \& Yamaguchi, M. (1997). World Vegetables: Principles, Production, and Nutritive Values. Chapman \& Hall. New 
York, New York.

61. Russo, V. M. (2008). Plant density and nitrogen fertilizer rate on yield and nutrient content of onion Developed from Greenhouse-grown Transplants. Hortscience. 43(6): 1759-1764

62. Sanon, M., Rouamba, A., \& Nicolas, H. (2001). Influence de l'irrigation sur le taux de montaison de l'oignon (Allium cepa L.) en première année de culture. Bulletin de la Recherche Agronomique. Num 34.

63. Shelton, A. M., Nault, B. A., Plate J., \& Zhao, J.Z. (2003). Regional and temporal variation in susceptibility to k-cyhalothrin in onion thrips, Thripstabaci (Thysanoptera: Thripidae), in onion fields in New York. J. Econ. Entomol. 96: 1843-1848.

64. Singer, S.M., Sawan, O.M., Abdel-Mouly, M.M., \& Salman, S.R. (1998). Study of the effects of Delta mix TM and organic matter on growth and productivity of bean plants grown under calcareous soil condition. Egypt. J. Hort. 25(3): 335-347.

65. Smith, R.., Biscaro, A., Cahn, M., Daugovish, O., Natwick, E., Nunez, J., Takele, E., \& Turini, T. (2011). Fresh-Market Bulb onion Production in California. University of California. Agriculture and Natural Resources. Publication 7242 http:// anrcatalog.ucdavis.edu.

66. Smith, R., Fennimore, S. A., Orloff, S., \& Poole, G. J. (2008). Bell, CE. Cudney, DW.

67. Tarchiani, V., Robbiati, G., \& Salifou, M. R. (2013). Filières oignon en Afrique de l'Ouest : étude comparée des filières nigérienne et béninoise. Cah Agric. 22: 112-23, doi : 10.1684/agr.2013.0617

68. Thorup-Kristensen, K. (2006). Root growth and nitrogen uptake of carrot, early cabbage, onion and lettuce following a range of green manures. Soil use and Mgt. 22:29-38.

69. Wicks, G. A., Johnstone, D. N., Nuland, D.S., \& Kinbacher, E. J. (1973). Competition between annual weeds and sweet Spanish onions. Weed Sci. 21: 436-439. 